\title{
Estimation of Groundwater Evapotranspiration of Different Dominant Phreatophytes in the Mu Us Sandy Region
}

\author{
Wuhui Jia ${ }^{1}$, Lihe Yin ${ }^{2, *}$, Maosheng Zhang ${ }^{3}$, Kun Yu ${ }^{2}$, Luchen Wang ${ }^{1,2}$ and Fusheng Hu ${ }^{1}$ \\ 1 School of Water Resources and Environment, China University of Geosciences, Beijing 100083, China; \\ jiawh@cugb.edu.cn (W.J.); wangluchen@cugb.edu.cn (L.W.); 1991010439@cugb.edu.cn (F.H.) \\ 2 Xi'an Center of Geological Survey, China Geological Survey, Xi'an 710054, China; yukun01@mail.cgs.gov.cn \\ 3 Institute of Disaster Prevention and Ecological Restoration, $\mathrm{Xi}^{\prime}$ an Jiaotong University, $\mathrm{Xi}^{\prime}$ an 710049, China; \\ xjtzms@xjtu.edu.cn \\ * Correspondence: ylihe@cgs.cn; Tel.: +86-29-8782-1680
}

check for updates

Citation: Jia, W.; Yin, L.; Zhang, M.; Yu, K.; Wang, L.; Hu, F. Estimation of Groundwater Evapotranspiration of Different Dominant Phreatophytes in the Mu Us Sandy Region. Water 2021, 13, 440. https://doi.org/10.3390/ w13040440

Academic Editors: Mirko Castellini, Simone Di Prima, Ryan Stewart, Marcella Biddoccu, Mehdi Rahmati and Vincenzo Alagna

Received: 7 January 2021

Accepted: 4 February 2021

Published: 8 February 2021

Publisher's Note: MDPI stays neutral with regard to jurisdictional claims in published maps and institutional affiliations.

Copyright: (c) 2021 by the authors. Licensee MDPI, Basel, Switzerland. This article is an open access article distributed under the terms and conditions of the Creative Commons Attribution (CC BY) license (https:// creativecommons.org/licenses/by/ $4.0 /)$.

\begin{abstract}
Groundwater evapotranspiration $\left(\mathrm{ET}_{\mathrm{G}}\right)$ estimation is an important issue in semiarid areas for groundwater resources management and environmental protection. It is widely estimated by diurnal water table fluctuations. In this study, the $\mathrm{ET}_{\mathrm{G}}$ at four sites with different plants was estimated using both diurnal water table and soil moisture fluctuations in the northeastern $\mathrm{Mu}$ Us sandy region, in order to identify the groundwater utilization strategy by different dominant phreatophytes. Groundwater level was monitored by ventilatory pressure transducers (Solinst LevelVent, Solinst Canada Ltd.; accuracy $\pm 3 \mathrm{~mm}$ ), while soil moisture was monitored using EM50 loggers (Decagon Devices Inc., Pullman, USA) in K1 and K14 and simulated by Hydrus-1D in other observation wells. A significant spatial variation of $\mathrm{ET}_{\mathrm{G}}$ was found within a limited area, indicating a poor representativeness of site $\mathrm{ET}_{\mathrm{G}}$ for regional estimation. The mean values of $\mathrm{ET}_{\mathrm{G}}$ are $4.01 \mathrm{~mm} / \mathrm{d}$, $6.03 \mathrm{~mm} / \mathrm{d}, 8.96 \mathrm{~mm} / \mathrm{d}$, and $12.26 \mathrm{~mm} / \mathrm{d}$ at the Achnatherum splendens site, Carex stenophylla site, Salix psammophila site and Populus alba site, respectively, for the whole growing season. $\mathrm{ET}_{\mathrm{G}}$ is more sensitive to depth to water table (DWT) in the Carex stenophylla site than in the Achnatherum splendens site for grass-dominated areas and more sensitive to DWT in the Populus alba site than in Salix psammophila site for tree-dominated areas. Groundwater extinction depths are estimated at $4.1 \mathrm{~m}$, $2.4 \mathrm{~m}, 7.1 \mathrm{~m}$, and $2.9 \mathrm{~m}$ in the Achnatherum splendens site, Carex stenophylla site, Salix psammophila site and Populus alba site, respectively.
\end{abstract}

Keywords: diurnal fluctuations; Phreatophyte; semiarid; wetland; vegetation restoration

\section{Introduction}

In arid and semi-arid areas, restoring and protecting the environment is a huge project for the benefit of mankind [1]. While groundwater is a crucial source of ecological restoration because of the lower precipitation and higher evapotranspiration in arid regions. However, these areas also depend heavily on groundwater for industry, drinking water supply and agriculture [2,3]. Reasonable allocation of groundwater resources in all sectors is thus a major environmental issue.

Groundwater is a main water source for phreatophytes in arid and semiarid areas. Evapotranspiration partitioning shows that transpiration accounts for the majority of evapotranspiration $[4,5]$. Over the past few decades, vegetation coverage has displayed a large increase because of the multiple ecological restoration programs including the grain for green and afforestation in some arid areas of China [6]. However, ecological restoration by afforestation may increase groundwater depth and create potentially large ecological and water costs in arid and semiarid [7]. For example, Gribovszki et al. [8] found that the water table beneath forest was $0.4-0.5 \mathrm{~m}$ lower than that beneath grassland due to the afforestation in the Hungarian Great Plain. So, the groundwater consumption strategy of each phreatophyte should be considered in the process of afforestation. 
In addition, groundwater evapotranspiration $\left(\mathrm{ET}_{\mathrm{G}}\right)$ is a vital factor for groundwater balance analysis in arid and simi-arid regions. For example, almost $60 \%$ of natural groundwater discharge is through $\mathrm{ET}_{\mathrm{G}}$ in the Ordos Plateau in NW China [9]. Many studies usually estimate $\mathrm{ET}_{\mathrm{G}}$ indirectly, i.e., by the pan coefficient method [10], the remote sensing method [11] and the eddy covariance method [12]. The pan coefficient method is simple, but coefficients mainly are empirical with low precision. The remote sensing method is usually used to calculate evapotranspiration at a regional scale and the time step depends on remote sensing data. It cannot analyze the temporal and spatial variation of evapotranspiration at small scale. The eddy covariance method depends on expensive instruments, so it is not widely used. In addition, all of these methods estimate rather total evapotranspiration than $\mathrm{ET}_{\mathrm{G}}$. Evapotranspiration partitioning is needed to exclude the contribution of soil water, which is a complicated process. Therefore, over the past few decades, the method of estimating evapotranspiration based on diurnal water table fluctuations, developed by White [13], has attracted more and more attention [14-18], because it can estimate $\mathrm{ET}_{\mathrm{G}}$ directly with fewer parameters and lower costs.

The Mu Us sandy region is a part of the Ordos Plateau in NW China and is used to be one of the most seriously desertified areas in China [19]. It has also undergone a significant vegetation restoration in recent decades [20]. While Cheng et al. [21] estimated the $\mathrm{ET}_{\mathrm{G}}$ at four sites in the center of the Mu Us sandy region, using only one observation at each site. However, the spatial variation of $\mathrm{ET}_{\mathrm{G}}$ at point scale under each vegetation is unclear and the representativeness of the $\mathrm{ET}_{\mathrm{G}}$ for one observation well is also uncertain. Multiple wells are expected to improve the accuracy of $\mathrm{ET}_{\mathrm{G}}$ estimation in each vegetation site [22]. Therefore, the objectives of this study are (1) to estimate the $\mathrm{ET}_{\mathrm{G}}$ from multiple observation wells based on the water table and soil moisture fluctuations at different sites; (2) to study the temporal and spatial variations of $\mathrm{ET}_{\mathrm{G}}$; and (3) to analyze the sensitivity of $\mathrm{ET}_{\mathrm{G}}$ of different vegetation to water table depth.

\section{Materials and Methods}

\subsection{Site Description}

The study site $\left(39^{\circ} 16^{\prime} 54^{\prime \prime} \sim 39^{\circ} 18^{\prime} 48^{\prime \prime} \mathrm{N}, 108^{\circ} 47^{\prime} 40^{\prime \prime} \sim 108^{\circ} 50^{\prime} 03^{\prime \prime} \mathrm{E}\right)$ is located in the northeastern $\mathrm{Mu}$ Us sandy region, within a wetland of the Mukai Lake in Ordos City, Inner Mongolia, NW China. The geomorphology is mainly lake basin that contains some microrelief, such as wetlands, crescent sand dunes, and highlands (Figure 1). Vegetation is distributed unevenly in the various microrelief. Vegetation coverage is higher in wetlands, up to about $70 \%$. While, there is only sparse vegetation on sand dunes. The climate is semi-arid characterized by a low rainfall and high evapotranspiration. According to the long-term meteorological data (2000-2017) from the Wushenzhao meteorological station near the study area, the mean annual precipitation is $\sim 330 \mathrm{~mm}$ and over $70 \%$ of the annual precipitation falls from June to September. Average reference evapotranspiration $\left(\mathrm{ET}_{0}\right)$ calculated by the Penman-Monteith equation [23] is $\sim 1150 \mathrm{~mm} / \mathrm{a}$. Average annual air temperature is about $7.0^{\circ} \mathrm{C}$, with a maximum of $22.4^{\circ} \mathrm{C}$ in July and a minimum of $-11.0^{\circ} \mathrm{C}$ in January. Population density is low and arable lands near the study area are scarce, so the consumption of groundwater by human activities is negligible.

The main species of vegetation are Achnatherum splendens (Figure 2a), Carex stenophylla (Figure 2b), Populus alba (Figure 2c), Salix psammophila (Figure 2d), and Caragana korshinskii (Figure 2e). The grass sites (Achnatherum splendens and Carex stenophylla) are distributed around the lake, while the tree sites (Populus alba, Salix psammophila and Caragana korshinskii) are located adjacent and upstream of the grass sites. 


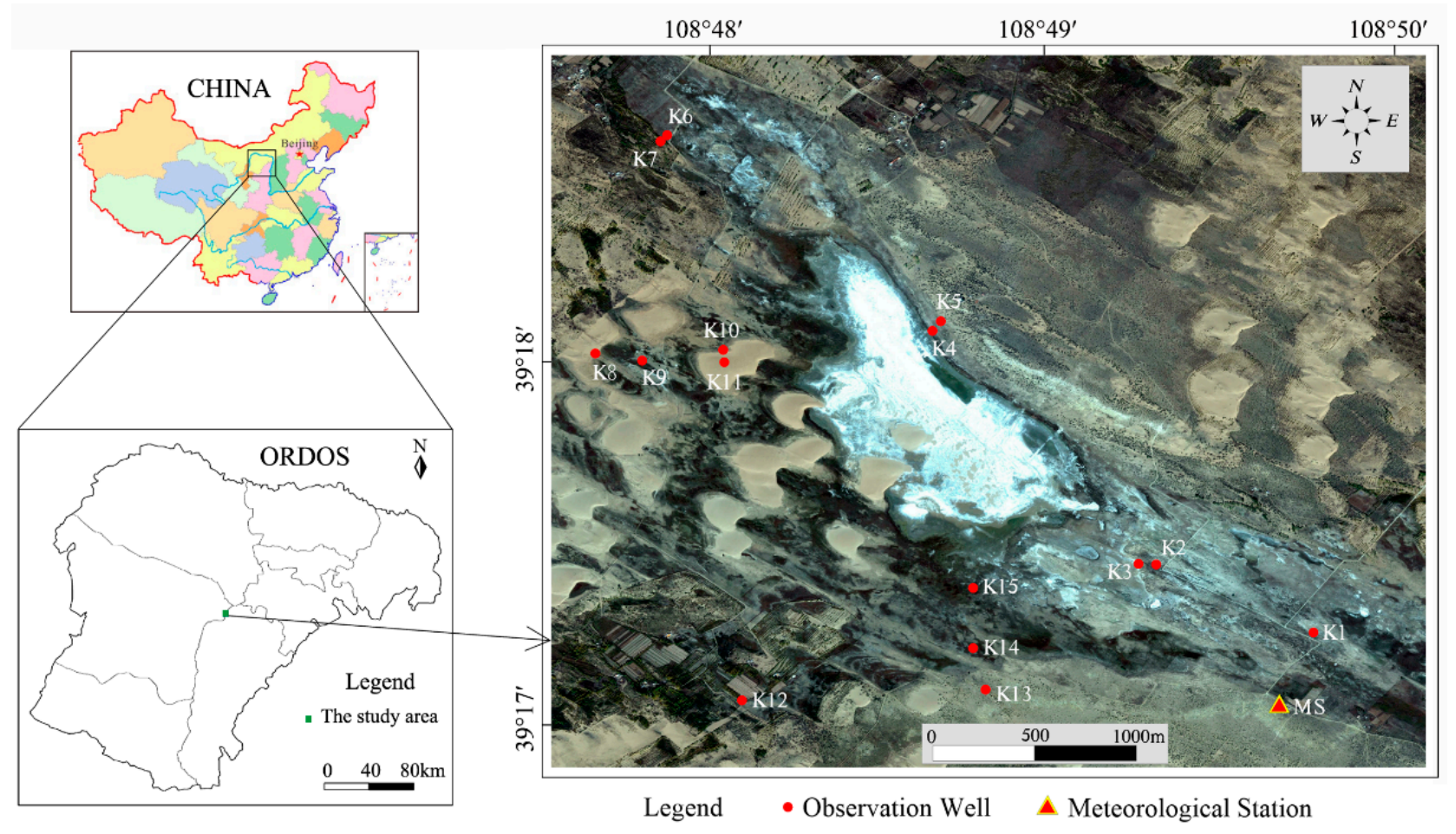

Figure 1. Location map of the study site showing the observation wells and meteorological station.

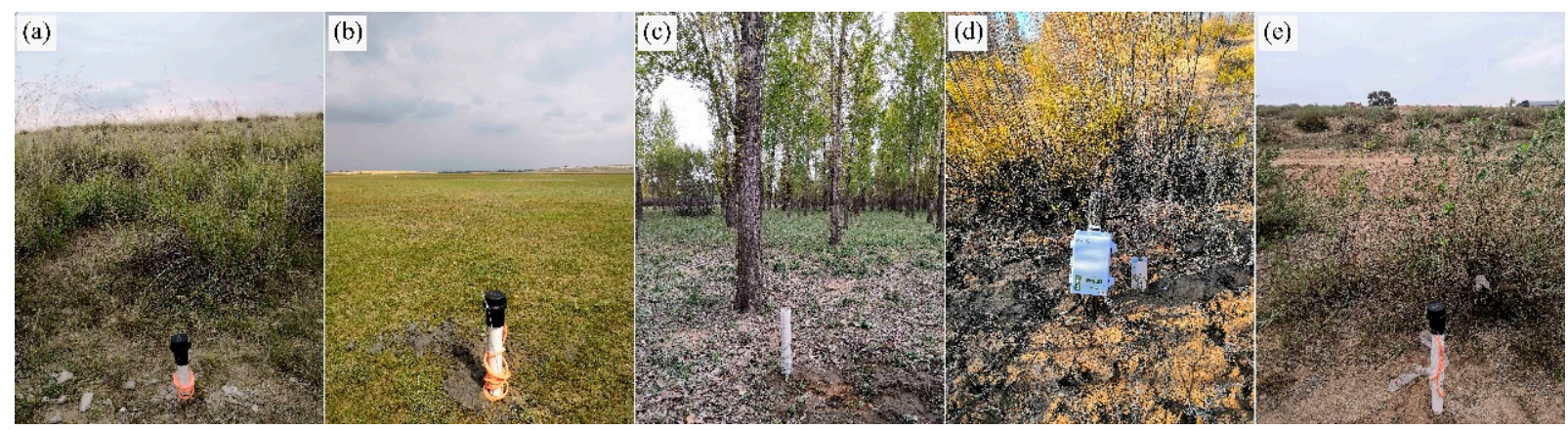

Figure 2. The dominate vegetations, i.e., (a) Achnatherum splendens, (b) Carex stenophylla, (c) Populus alba, (d) Salix psammophila and (e) Caragana korshinskii, in the study site.

\subsection{Monitoring Design}

Fifteen shallow observation wells (K1 to K15) were drilled by a hand auger around the lake (Figure 1). K1, K2, and K3 are in the Achnatherum splendens site; K4, K9, K10, K14, and K15 are in the Carex stenophylla site; K5 and K13 are in the Caragana korshinskii site; K6, K7 are in the Salix psammophila site; K8 and K11 are located in sand dunes; K12 is in the Populus alba site. The depth of the wells varies between $2 \mathrm{~m}$ and $4 \mathrm{~m}$, depending on the depth to water table (DWT) at each site. Each was constructed using a $50 \mathrm{~mm}$ PVC pipe screened over the entire subsurface length. Augured soil was backfilled around the PVC pipe and granular bentonite was then packed around land surface to avoid preferential flow.

Groundwater level was continuously monitored from 1 April 2019 to 31 October 2019 at one-hour intervals by ventilatory pressure transducers with data logging capability (Solinst LevelVent, Solinst Canada Ltd.; accuracy $\pm 3 \mathrm{~mm}$ ) that automatically eliminated the effect of air pressure fluctuations by a vented cable to the wellhead. The well cap assembly of the transducers serves to prevent direct rainfall input and evaporation loss. In order to remove noise, a five-point moving average was used to smoothen groundwater level 
data [18]. The data were also calibrated frequently in the field with manual measurements of DWT.

Soil samples were collected from different depths and the particle sizes were determined by the sieving method for the sand fractions and by a soil hydrometer for the silt and clay fractions. Results showed that the soil texture of unsaturated zone at the study sites was mainly fine sand and homogeneous in the vertical direction at each well (Table 1). The soil textures of all observation wells were divided artificially into two categories, with sand content higher than $90 \%$, and with sand content less than $90 \%$. Then, two observation sites, $\mathrm{K} 1$ and $\mathrm{K} 14$, were thought to be representative of the two soil textures. Soil moisture $\left(\theta_{\mathrm{s}}\right)$ was monitored once an hour from $20 \mathrm{~cm}$ to $100 \mathrm{~cm}$ below ground surface with $20 \mathrm{~cm}$ intervals at $\mathrm{K} 1$ and from $20 \mathrm{~cm}$ to $60 \mathrm{~cm}$ with $10 \mathrm{~cm}$ intervals at K14 using EM50 loggers (Decagon Devices Inc., Pullman, USA).

Table 1. Particle size distribution at different depths in the Observation wells.

\begin{tabular}{|c|c|c|c|c|}
\hline Wells & Soil Depth (cm) & Sand (\%) & Silt (\%) & Clay (\%) \\
\hline \multirow{3}{*}{ K1 } & 40 & 82.9 & 17.1 & 0 \\
\hline & 60 & 83.4 & 16.6 & 0 \\
\hline & 80 & 86.3 & 13.7 & 0 \\
\hline \multirow{2}{*}{$\mathrm{K} 3$} & 50 & 85.0 & 15.0 & 0 \\
\hline & 70 & 85.1 & 14.9 & 0 \\
\hline \multirow{3}{*}{ K4 } & 20 & 85.5 & 14.5 & 0 \\
\hline & 50 & 83.2 & 16.8 & 0 \\
\hline & 70 & 81.9 & 18.1 & 0 \\
\hline \multirow{2}{*}{ K6 } & 50 & 91.0 & 9.0 & 0 \\
\hline & 80 & 91.1 & 8.9 & 0 \\
\hline \multirow{2}{*}{ K9 } & 20 & 85.6 & 14.4 & 0 \\
\hline & 50 & 85.2 & 14.8 & 0 \\
\hline \multirow{2}{*}{ K10 } & 20 & 92.7 & 7.3 & 0 \\
\hline & 50 & 94.7 & 5.3 & 0 \\
\hline \multirow{3}{*}{ K12 } & 50 & 92.4 & 7.6 & 0 \\
\hline & 80 & 92.9 & 7.1 & 0 \\
\hline & 100 & 95.7 & 4.3 & 0 \\
\hline \multirow{3}{*}{ K14 } & 30 & 98.0 & 2.0 & 0 \\
\hline & 60 & 98.4 & 1.6 & 0 \\
\hline & 80 & 92.6 & 7.4 & 0 \\
\hline K15 & 20 & 87.2 & 12.8 & 0 \\
\hline
\end{tabular}

Meteorological data (i.e., solar radiation, air temperature, air humidity, and wind speed) were monitored at one-hour intervals by a meteorological station (HOBO-U30, Onset, USA) at the southeast of study site. Hourly reference evapotranspiration $\left(\mathrm{ET}_{0}\right)$ was calculated by the Penman-Monteith Equation (Equation (1)) using the meteorological data [23].

$$
\mathrm{ET}_{0}=\left[0.408 \Delta\left(\mathrm{R}_{\mathrm{n}}-\mathrm{G}\right)+37 \gamma \mu\left(\mathrm{e}^{\circ}\left(\mathrm{T}_{\mathrm{h}}\right)-\mathrm{e}_{\mathrm{a}}\right) /\left(\mathrm{T}_{\mathrm{h}}+273\right)\right] /[\Delta+\gamma(1+0.34 \mu)] .
$$

where $\mathrm{ET}_{0}$ is reference evapotranspiration $\left(\mathrm{mm} \cdot \mathrm{h}^{-1}\right) ; \mathrm{R}_{\mathrm{n}}$ is net radiation $\left(\mathrm{MJ} \cdot \mathrm{m}^{-2} \cdot \mathrm{h}^{-1}\right) ; \mathrm{G}$ is soil heat flux density (MJ. $\left.\mathrm{m}^{-2} \cdot \mathrm{h}^{-1}\right) ; \mathrm{T}_{\mathrm{h}}$ is mean hourly air temperature $\left({ }^{\circ} \mathrm{C}\right) ; \Delta$ is saturation slope vapor pressure curve at $\mathrm{T}_{\mathrm{h}}\left(\mathrm{kPa} \cdot{ }^{\circ} \mathrm{C}^{-1}\right) ; \gamma$ is psychrometric constant $\left(\mathrm{kPa} \cdot{ }^{\circ} \mathrm{C}^{-1}\right) ; \mathrm{e}^{\circ}\left(\mathrm{T}_{\mathrm{h}}\right)$ is saturation vapor pressure at air temperature $\mathrm{T}_{\mathrm{h}}(\mathrm{kPa}) ; \mathrm{e}_{\mathrm{a}}$ is average hourly actual vapor pressure $(\mathrm{kPa}) ; \mu$ is average hourly wind speed $\left(\mathrm{m} \cdot \mathrm{s}^{-1}\right)$. It is worth noting that $\mathrm{ET}_{0}$ is the evapotranspiration from the reference surface which is under a hypothetical grass reference crop with an assumed crop height of $0.12 \mathrm{~m}$, a fixed surface resistance of $70 \mathrm{~s} \cdot \mathrm{m}^{-1}$ and an albedo of 0.23 . The reference surface closely resembles an extensive surface of green, 
well-watered grass of uniform height, actively growing and completely shading the ground. The fixed surface resistance of $70 \mathrm{~s} \cdot \mathrm{m}^{-1}$ implies a moderately dry soil surface resulting from about a weekly irrigation frequency [23].

\subsection{Numerical Simulations}

\subsubsection{Soil Hydraulic Parameters Estimated by Inverse Modeling}

Soil hydraulic parameters were obtained through inverse modeling by Hydrus-1D, which was widely used by previous studies [24-26]. For K1 and K14, as the representative of the two soils, both groundwater level and soil moisture were monitored. Therefore, the meteorological data, water table and soil moisture data were used to inverse soil hydraulic parameters of the two soil textures in the study site.

For the inverse modeling, a $150 \mathrm{~cm}$ homogeneous soil profile was divided uniformly into 150 elements, with 151 nodes and two observations corresponding to the soil moisture monitoring depths $(20 \mathrm{~cm}$ and $100 \mathrm{~cm}$ at $\mathrm{K} 1 ; 20 \mathrm{~cm}$ and $40 \mathrm{~cm}$ at K14). The maximum number of iterations was set to 50 . The van Genuchten-Mualem hydraulic model was selected and the soil hydraulic parameters of loamy sand in the model were used as the initial parameters because the soil texture is classified as loamy sand based on particle size analysis. The maximum and minimum values of each parameter, i.e., $\theta_{\mathrm{s}}, \theta_{\mathrm{r}}, \varphi$, n, and Ks, are set to limit the range of inversion. According to the particle analysis of soils in the study site (Table 1), the maximum values of $\varphi, \mathrm{n}$ and Ks were set to the default parameters of sand in Hydrus-1D code and the minimum values equaled to the default parameters of silt, as shown in Table 2. Data for inverse solution were soil moisture data measured in the field at the two observations depths. Time discretization was in hours and initial time step was set to 0.01 .

Table 2. The initial, minimum and maximum values of the soil hydraulic parameters in inverse solution.

\begin{tabular}{cccccc}
\hline & $\theta_{\mathrm{r}}\left(\mathrm{cm}^{3} / \mathrm{cm}^{3}\right)$ & $\theta_{\mathrm{s}}\left(\mathrm{cm}^{3} / \mathrm{cm}^{3}\right)$ & $\varphi(\mathbf{1} / \mathbf{c m})$ & $\mathbf{n}$ & $\mathbf{K}_{\mathbf{s}}(\mathbf{c m} / \mathbf{h})$ \\
\hline Initial Value & 0.057 & 0.41 & 0.124 & 2.28 & 14.5917 \\
Minimum & 0 & 0 & 0.016 & 1.37 & 0.25 \\
Maximum & 0.078 & 0.43 & 0.145 & 2.68 & 29.7 \\
\hline
\end{tabular}

The upper boundary condition was defined as an atmospheric boundary condition. The potential evapotranspiration $\left(\mathrm{ET}_{\mathrm{p}}\right)$ equals to $\mathrm{ET}_{0}$ as recommended by Šimůnek et al. [27], and the potential evaporation $\left(\mathrm{E}_{\mathrm{p}}\right)$ and potential transpiration $\left(\mathrm{T}_{\mathrm{p}}\right)$ were estimated from $\mathrm{ET}_{\mathrm{p}}$ using Beer's law that partitions the solar radiation component of the energy budget via interception by the canopy [28,29] as follows in Equations (2) and (3):

$$
\begin{gathered}
\mathrm{E}_{\mathrm{p}}=\mathrm{ET}_{\mathrm{p}} \times \mathrm{e}^{-\mathrm{k}^{*} \mathrm{LAI}} \\
\mathrm{T}_{\mathrm{p}}=\mathrm{ET}_{\mathrm{p}} \times\left(1-\mathrm{e}^{-\mathrm{k}^{*} \mathrm{LAI}}\right)
\end{gathered}
$$

where $\mathrm{k}$ is a constant governing the radiation extinction by the canopy $(-)$, the value is about 0.6 according to Belmans et al. [30]. LAI is the leaf area index and the values in grass site and tree site are 1.9 and 2.6, respectively. The lower boundary condition was variable pressure head that was monitored in the study site. The period of the inverse model was from 20 May 2019 to 5 June 2019 for K1 and from 24 May 2019 to 6 September 2019 for K14, when obvious diurnal fluctuations of water table and soil water moisture continuously occurred.

In the study site, the root depth was about $150 \mathrm{~cm}$. An exponential root distribution model developed by Zeng [31] was used in our model, as follow in Equation (4):

$$
\mathrm{Y}=1-0.5\left(\mathrm{e}^{-\mathrm{ad}}+\mathrm{e}^{-\mathrm{bd}}\right)
$$


where $\mathrm{Y}$ is the cumulative root fraction from the surface to depth $\mathrm{d}$; $\mathrm{a}$ and $\mathrm{b}$ are the empirical coefficients. For short grass, a and b are 10.74 and 2.61, respectively. The S-shaped water stress function of root water uptake was adopted [32].

\subsubsection{Simulated Soil Moisture}

Soil moisture was monitored at K1 and K14 and simulated by Hydrus-1D at other observation wells, because of the lack of monitoring equipment. The simulation domain is a $150 \mathrm{~cm}$ homogeneous soil profile and was divided uniformly into 150 elements with 151 nodes. The simulated period was from 1 April 2019 to 31 October 2019 and the soil hydraulic parameters were from the above-mentioned inverse modelling. The upper boundary condition was also atmospheric boundary condition. $E_{p}$ and $T_{p}$ were also estimated by Equations (2) and (3). The lower boundary condition was also defined as a variable pressure head condition. Root depth was $150 \mathrm{~cm}$ in the grass site and $200 \mathrm{~cm}$ in the areas with arboreous vegetation. The root water uptake model and root distribution model are same to the models used in the previous section. While the parameters $a$ and $b$ in the root distribution model are 7.07 and 1.95, respectively, for deciduous needleleaf tree, i.e., Salix psammophila, and are 5.99 and 1.96, respectively, for deciduous broadleaf tree, i.e., Populus alba, according to Zeng [31]. The observation points were set from the land surface to water table with $10 \mathrm{~cm}$ intervals to obtain soil moisture along the soil profile. To test the accuracy of the simulated data, the soil moisture of K1 $(60 \mathrm{~cm}$ and $80 \mathrm{~cm}$ depth) and K14 (50 $\mathrm{cm}$ and $70 \mathrm{~cm}$ depth) were also simulated and then compared to the measured data.

\subsubsection{Statistical Analysis}

The root mean square error (RMSE), Nash-Sutcliffe efficiency (NSE) and percent bias (PBIAS) were used to compare the observed and simulated soil moisture. They are defined as Equations (5)-(7), respectively, as followed:

$$
\begin{gathered}
\text { RMSE }=\sqrt{ }\left[\left(\sum_{\mathrm{i}}^{\mathrm{n}}\left(\theta_{\text {obs }, \mathrm{i}}-\theta_{\text {sim }, \mathrm{i}}\right)^{2}\right) / \mathrm{n}\right] \\
\mathrm{NSE}=1-\Sigma_{\mathrm{i}}^{\mathrm{n}}\left(\theta_{\text {obs, } \mathrm{I}}-\theta_{\text {sim, } \mathrm{i}}\right)^{2} / \Sigma_{\mathrm{i}}^{\mathrm{n}}\left(\theta_{\text {obs, } \mathrm{I}}-\operatorname{ave}_{\text {obs, } \mathrm{i}}\right)^{2} \\
\text { PBIAS }=100 \times\left[\Sigma_{\mathrm{i}}^{\mathrm{n}}\left(\theta_{\text {sim, } \mathrm{I}}-\theta_{\text {obs, } \mathrm{i}}\right) / \Sigma_{\mathrm{i}}^{\mathrm{n}} \theta_{\text {obs, } \mathrm{i}}\right]
\end{gathered}
$$

where $\theta_{\text {obs }}$ is the observed soil moisture in field, $\theta_{\text {sim }}$ is the simulated soil moisture, $n$ is the number of observations, ave $\theta_{\text {obs }}$ is the average soil moisture of all the observed events.

RMSE indicates the degree of dispersion of the simulated soil moisture relative to the observed moisture [33], and a higher value indicates a higher error in the simulated moisture. NSE represents the extent to which the simulated moisture and the observed moisture follow a 1:1 slope line [34]. It ranges from $-\infty$ to 1 and higher values indicate a better agreement with the observed moisture [35]. PBIAS measures the average tendency of the simulated values to be larger or smaller than their observed ones. The optimal value of PBIAS is 0.0 , with small values indicating accurate model simulation. Positive values indicate overestimation bias, and negative values indicate model underestimation bias.

\section{4. $E T_{G}$ Estimation}

White [13] initially developed a method to quantify daily ET $_{\mathrm{G}}$ using diurnal water table fluctuations (hereafter referred to as the White method [36]), as follows in Equation (8):

$$
\mathrm{ET}_{\mathrm{G}}=\mathrm{S}_{\mathrm{y}} \times(24 \mathrm{r} \pm \mathrm{s})
$$

where $\mathrm{ET}_{\mathrm{G}}$ is the daily groundwater evapotranspiration $\left(\mathrm{L} \cdot \mathrm{T}^{-1}\right), \mathrm{S}_{\mathrm{y}}$ is the specific yield of sediments $(-), \mathrm{r}$ is the rate of water table recovery during nighttime $\left(\mathrm{L} \cdot \mathrm{T}^{-1}\right)$ and $\mathrm{s}$ is the daily change in storage $\left(\mathrm{L} \cdot \mathrm{T}^{-1}\right)$

In this study, a modified White method was adopted to estimate the daily $\mathrm{ET}_{\mathrm{G}}$. For the method, daily hydrostatic equilibrium recovery $\left(R_{e}\right)$ is proposed to correct the groundwater inflow estimated by the White method, taking the disequilibrium of soil 
water into consideration. The hydrostatic equilibrium at the capillary zone is disturbed at the moment when root water uptake commences in the morning, then the degree of deviation from hydrostatic equilibrium increases in daytime due to the higher ET rate than the hydrostatic equilibrium recovery rate. So, capillary water continues to be replenished by groundwater to lower the degree of deviation from hydrostatic equilibrium at night, resulting in groundwater inflow being underestimated by water table recovery in the White method. Thus, daily $R_{e}$ is estimated by extending the capillary water recovery rate at nighttime to the whole day, representing the error of daily groundwater inflow estimated by the White method. The procedure for calculating $R_{\mathrm{e}}$ is quite similar to that of the recovery rate ( $r$ in Equation (8)) in the White method. The first step is the calculation of the deviation of total soil water (TSW) from hydrostatic equilibrium, (TSW eq $-\mathrm{TSW}_{\mathrm{s}}$ ), at two specified times (i.e., 22:00 and 6:00 in this study) during nighttime, respectively, then the difference between $\left(\mathrm{TSW}_{\mathrm{eq}}-\mathrm{TSW}_{\mathrm{s}}\right.$ ) of both points of time is determined, and finally the daily $R_{e}$ is calculated by multiplying by $24 \mathrm{~h}$. Equations (9) and (10) are the mathematical expressions for $\mathrm{R}_{\mathrm{e}}$ :

$$
\mathrm{R}_{\mathrm{e}}=24 \times\left[\left(\mathrm{TSW}_{\mathrm{eq}}-\mathrm{TSW}_{\mathrm{s}}\right)_{\mathrm{t}}-\left(\mathrm{TSW}_{\mathrm{eq}}-\mathrm{TSW}_{\mathrm{s}}\right)_{\mathrm{t}+\Delta \mathrm{t}}\right] / \Delta \mathrm{t}
$$

and

$$
\mathrm{TSW}=\int \mathrm{d} \theta \mathrm{dz}=\Sigma_{\mathrm{j}}^{\mathrm{d}} 0.5 \times\left(Z_{\mathrm{j}+1}-\mathrm{Z}_{\mathrm{j}}\right) \times\left(\theta_{\mathrm{j}+1}+\theta_{\mathrm{j}}\right)
$$

where $\mathrm{TSW}_{\mathrm{eq}}$ is the TSW in the column for the corresponding DWT under hydrostatic equilibrium conditions (L); TSW $\mathrm{T}_{\mathrm{S}}$ is the TSW computed from the field measured water content values $(\mathrm{L}) ; \theta$ is water content $\left(\mathrm{L}^{3} \cdot \mathrm{L}^{-3}\right)$; $\mathrm{j}$ is the soil moisture monitoring point of the soil column. Then the daily $\mathrm{ET}_{\mathrm{G}}$ was estimated as follows in Equation (11):

$$
\mathrm{ET}_{\mathrm{G}}=\mathrm{S}_{\mathrm{y}}(24 \mathrm{r} \pm \mathrm{s})+\mathrm{R}_{\mathrm{e}}
$$

The soil moisture under a hydrostatic equilibrium condition was calculated using the van Genuchten soil water retention properties (Equations (12) and (13)).

$$
\begin{gathered}
\theta(\mathrm{h})=\theta_{\mathrm{r}}+\left(\theta_{\mathrm{s}}-\theta_{\mathrm{r}}\right) /\left[1+(\varphi|\mathrm{h}|)^{\mathrm{n}}\right]^{\mathrm{m}}, \mathrm{h}<0 \\
\theta(\mathrm{h})=\theta_{\mathrm{s}}, \mathrm{h} \geq 0
\end{gathered}
$$

where $h$ is the water pressure head $(\mathrm{L}), \theta_{\mathrm{S}}$ and $\theta_{\mathrm{r}}$ are the saturated and residual soil moisture $\left(\mathrm{L}^{3} \cdot \mathrm{L}^{-3}\right)$, respectively, $\varphi$ is the air entry value also referred as bubble pressure $\left(\mathrm{L}^{-1}\right), \mathrm{n}$ is the pore size distribution parameter $(-), \mathrm{m}=1-1 / \mathrm{n}(-)$, and $\varphi, \mathrm{n}$, and $\mathrm{m}$ are the empirical shape factors in the water retention function.

It should be noted that specific yield $\left(\mathrm{S}_{\mathrm{y}}\right)$ is the most crucial factor for $\mathrm{ET}_{\mathrm{G}}$ estimation by water table fluctuations [37-39]. $\mathrm{S}_{\mathrm{y}}$ is defined as the volume of water released under gravity from storage per unit cross sectional area per unit decline in water table [40]. It is affected by soil texture, depth to water table and drainage time [38]. So, the depthdependent and time-dependent $\mathrm{S}_{\mathrm{y}}$ are widely used to estimate $\mathrm{ET}_{\mathrm{G}}$ based on water table fluctuations [21,37].

In this study, the drainage time is not taken into account because the change of capillary water has been calculated. Therefore, the equation for depth-dependent $S_{y}$ developed by Duke [41] with van Genuchten parameters was used (Equation (14))

$$
\mathrm{S}_{\mathrm{y}}=\theta_{\mathrm{s}}-\left[\theta_{\mathrm{r}}+\left(\theta_{\mathrm{s}}-\theta_{\mathrm{r}}\right) /\left[1+(\varphi \mid \mathrm{d} l)^{\mathrm{n}}\right]^{\mathrm{m}}\right]
$$

where $\mathrm{d}$ is the depth to water table (L). 


\section{Results and Discussion}

\subsection{Soil Hydraulic Parameters}

The measured and simulated soil moisture from inverse modelling at two depths for each observation well (K1 and K14) are shown in Figure 3. The RMSE, NSE, PBIAS, and $R$-square $\left(R^{2}\right)$ of measured and simulated data were $0.003 \mathrm{~cm}^{3} / \mathrm{cm}^{3}, 0.99,-0.04 \%$, and 0.99 , respectively, for K1, while for K14, the RMSE, NSE, PBIAS, and $\mathrm{R}^{2}$ of measured and simulated data were $0.015 \mathrm{~cm}^{3} / \mathrm{cm}^{3}, 0.86,1.22 \%$, and 0.81 , respectively. According to the statistical analysis, the simulated soil hydraulic parameters of K1 and K14, as showed in Table 3, were a good representation of the actual field parameters.
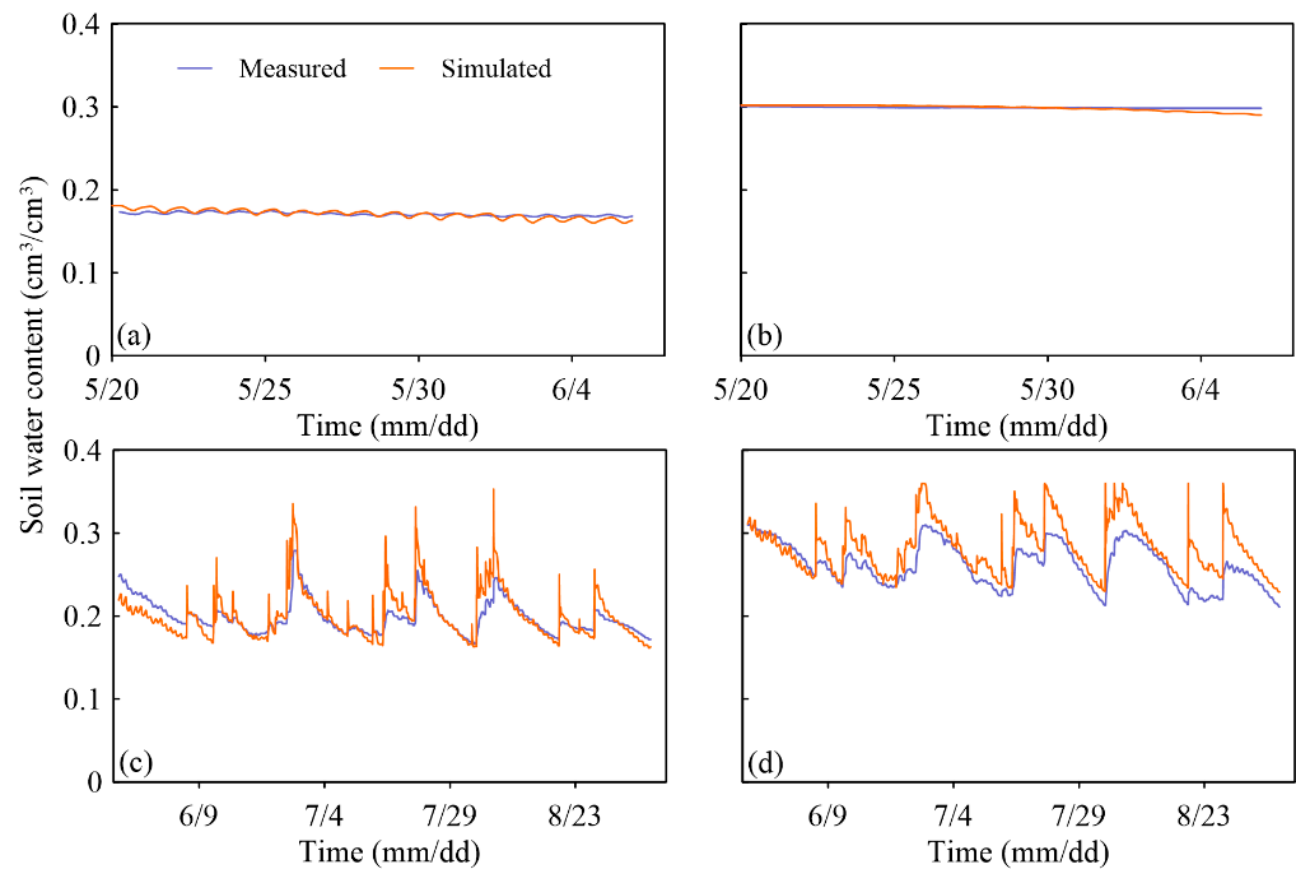

Figure 3. The measured and simulated data of soil moisture at (a) $20 \mathrm{~cm}$ depth and (b) $100 \mathrm{~cm}$ depth for $\mathrm{K} 1$, and (c) $20 \mathrm{~cm}$ depth and (d) $40 \mathrm{~cm}$ depth for $\mathrm{K} 14$.

Table 3. Simulated soil hydraulic parameters for K1 and K14.

\begin{tabular}{cccccc}
\hline Well & $\theta_{\mathbf{r}}\left(\mathbf{c m}^{3} / \mathbf{c m}^{3}\right)$ & $\theta_{\mathbf{s}}\left(\mathbf{c m}^{3} / \mathbf{c m}^{3}\right)$ & $\varphi(\mathbf{1} / \mathbf{c m})$ & $\mathbf{n}$ & $\mathbf{K}_{\mathbf{s}}(\mathbf{c m} / \mathbf{h})$ \\
\hline K1 & 0.0453 & 0.302 & 0.0253 & 1.78 & 14.2 \\
K14 & 0.0532 & 0.387 & 0.0282 & 2.68 & 29.4 \\
\hline
\end{tabular}

\subsection{Validation of the Simulated Soil Moisture}

Soil moisture was also simulated at K1 and K14 to assess the accuracy of the modelled soil moisture, using the measured and simulated soil moisture at $60 \mathrm{~cm}$ and $80 \mathrm{~cm}$ for K1 and $50 \mathrm{~cm}$ and $70 \mathrm{~cm}$ for K14. As shown in Figure 4 and Table 4, the simulated soil moisture has a good agreement with the measured data, with the mean RMSE of $0.012 \mathrm{~cm}^{3} / \mathrm{cm}^{3}$ at $\mathrm{K} 1$ and $0.019 \mathrm{~cm}^{3} / \mathrm{cm}^{3}$ at K14. While the NSE and $\mathrm{R}^{2}$ at K14 are 0.25 and 0.21 , respectively. The possible reason is that the sensitivity of the monitoring instrument decreases due to the observation depth being close to water table. 

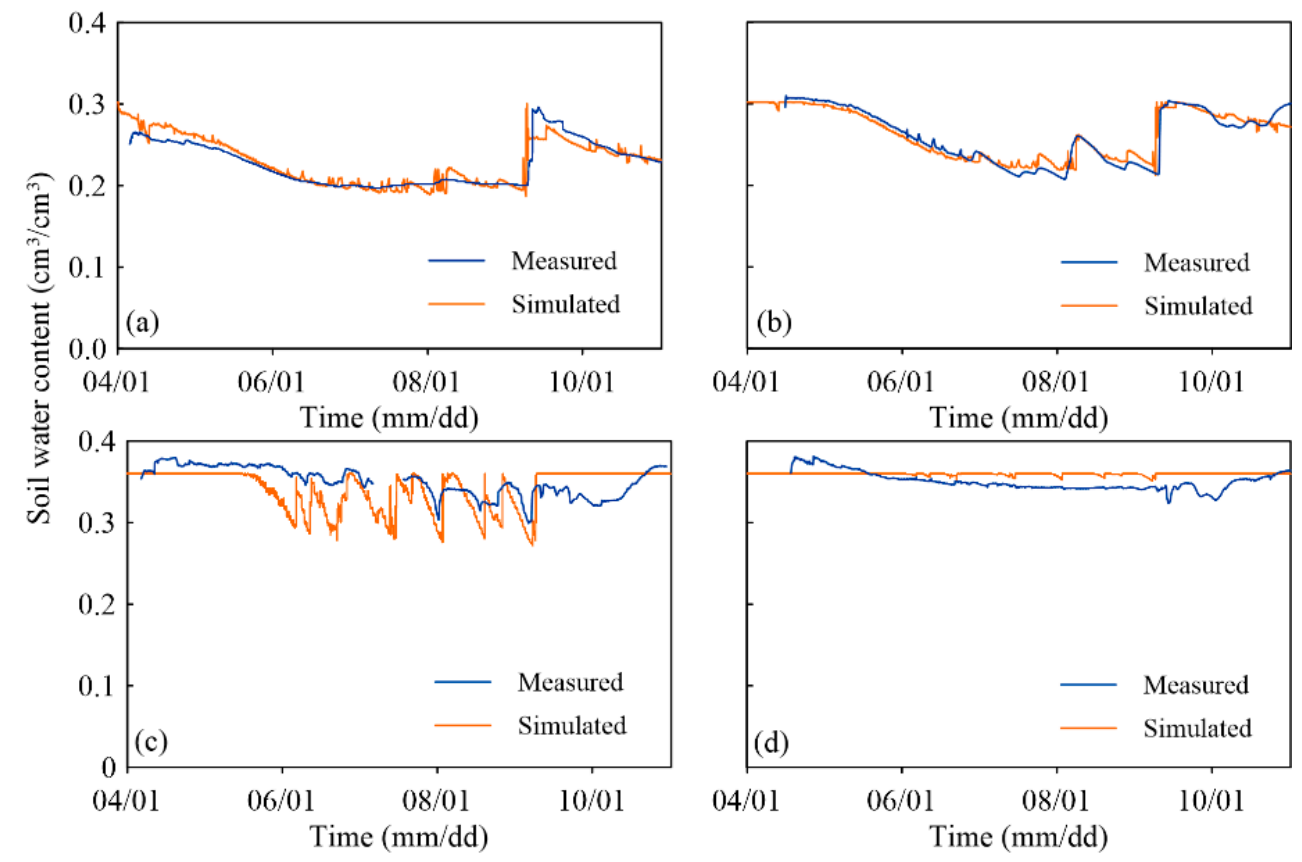

Figure 4. The measured and simulated data of soil moisture at (a) $60 \mathrm{~cm}$ depth and (b) $80 \mathrm{~cm}$ depth for $\mathrm{K} 1$, and (c) $50 \mathrm{~cm}$ depth and (d) $70 \mathrm{~cm}$ depth for K14.

Table 4. The root mean square error (RMSE), Nash-Sutcliffe efficiency (NSE), percent bias (PBIAS) and R-square $\left(\mathrm{R}^{2}\right)$ of the measured and simulated soil moisture for K1 and K14.

\begin{tabular}{ccccc}
\hline & $\begin{array}{c}\text { RMSE } \\
\left(\mathbf{c m}^{3} / \mathbf{c m}^{3}\right)\end{array}$ & NSE & PBIAS (\%) & $\mathbf{R}^{\mathbf{2}}$ \\
\hline K1 & 0.012 & 0.88 & 0.18 & 0.89 \\
K14 & 0.019 & 0.25 & -1.82 & 0.21 \\
\hline
\end{tabular}

\subsection{Temporal and Spatial Variations of Water Table}

Obvious diurnal water table fluctuation occurred during the whole growing season in the field. As shown in Figure 5a and b, groundwater table fell during daytime and recovered during nighttime. The variation pattern of water table at sub-daily scale is mainly caused by the evapotranspiration of vegetation. While solar radiation is a dominant factor controlling plant water use in sub-daily scale [42,43], and further influences water table variations (Figure $5 c$ ).

The changes in water table at seasonal scales are reflected in daily amplitudes. For the Carex stenophylla site, the average daily amplitudes of water table at $K 10$ are $1.7 \mathrm{~cm}, 2.3 \mathrm{~cm}$, and $1.4 \mathrm{~cm}$ in the early, middle, and late of the growing season, respectively (Figure 5a). While they are $2.3 \mathrm{~cm}, 4.1 \mathrm{~cm}$, and $1.3 \mathrm{~cm}$, respectively, at K12 in the Populus alba site (Figure 5b). Obviously, the daily amplitude of water table in the middle of the growing season is larger than that in the early and late of the growing season. It is mainly caused by the vegetation vitality that depends on air temperature (Figure $5 \mathrm{~d}$ ).

The patterns of water table fluctuation in the field are also different for various DWT. In the Achnatherum splendens site, the mean daily amplitude of water table is $0.2 \mathrm{~cm}$ with an average DWT of $1.85 \mathrm{~m}$ at K2 from 21 May to 25 May (Figure 6a). At K3, the mean daily amplitude of water table is $0.6 \mathrm{~cm}$ with an average DWT of $0.71 \mathrm{~m}$ in the same period. In addition, the mean daily amplitude of water table at $\mathrm{K} 6$ and $\mathrm{K} 7$ are $5.8 \mathrm{~cm}$ and $1.8 \mathrm{~cm}$ with average DWT of $0.99 \mathrm{~m}$ and $1.67 \mathrm{~m}$, respectively, from 1 July to 5 July in the Salix psammophila site (Figure 6b). Obviously, the daily amplitude of water table with shallow water table is larger than that with deep water table in the same vegetation condition, 
mainly resulting from the decrease of root distribution and increase of specific yield with DWT.
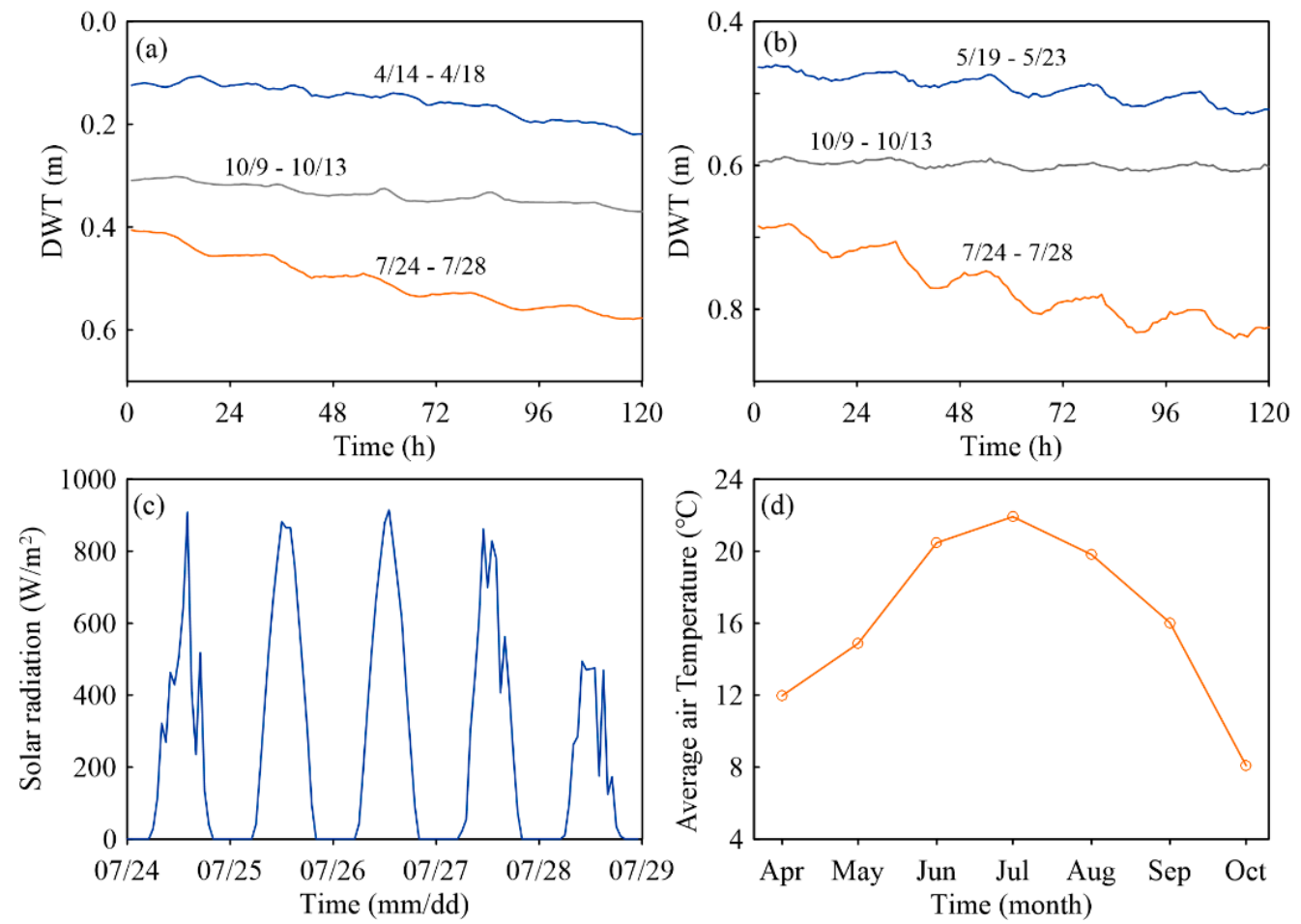

Figure 5. The depth of water table (DWT) of K10 (a) and K12 (b) at the different periods of the growing season; (c) the variation of hourly solar radiation during 24 to 28 July and (d) monthly average air temperature.
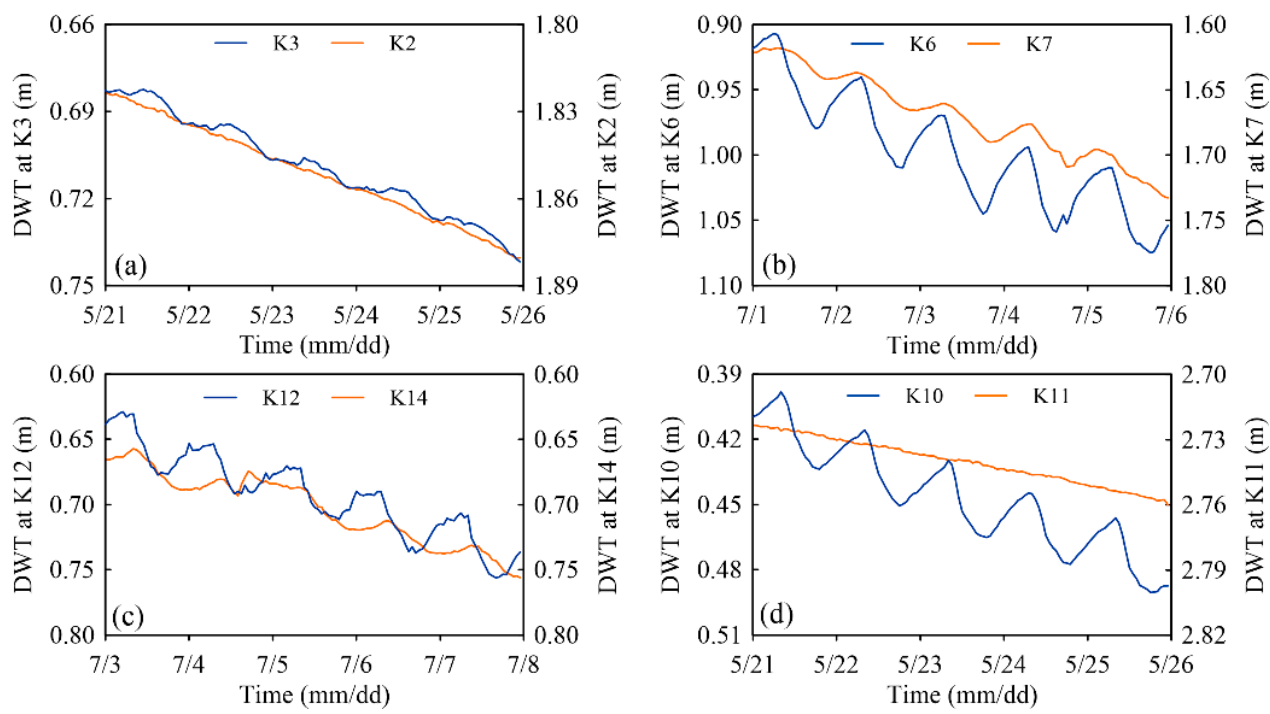

Figure 6. The water table fluctuations vary with (a) the DWT in Achnatherum splendens site and (b) the DWT in Salix psammophila site, (c) the vegetation conditions in the same DWT, and (d) the microrelief.

Vegetation condition is also a vital influencing factor of water level fluctuation pattern. For example, the daily amplitude of water table $(3.7 \mathrm{~cm})$ at $\mathrm{K} 12$ in the Populus alba site is larger than that $(2.0 \mathrm{~cm})$ at K14 in the Carex stenophylla site with the same average DWT of $0.70 \mathrm{~m}$ (Figure 6c). Furthermore, K10 is in the Carex stenophylla site and a sand dune at a distance of $20 \mathrm{~m}$ from $\mathrm{K} 10$ is free of vegetation. There is obviously water table fluctuation at K10 but no water table fluctuation at K11 (Figure 6d). The water table shows no fluctuation 
at $\mathrm{K} 5$ and $\mathrm{K} 13$ either, indicating that water table fluctuation is not influenced by other factors, such as tidal [44,45] and barometric pressure [46].

\subsection{Groundwater Evapotranspiration}

\subsubsection{Temporal Variations of $\mathrm{ET}_{\mathrm{G}}$}

$\mathrm{ET}_{\mathrm{G}}$ was estimated except for the wells with no diurnal water table fluctuations, i.e., $\mathrm{K} 5, \mathrm{~K} 11$, and $\mathrm{K} 13$, indicating that Caragana korshinskii is a plant independent of groundwater. There were no $\mathrm{ET}_{\mathrm{G}}$ data on rainy days due to the inapplicability of the estimated method. Average daily $\mathrm{ET}_{\mathrm{G}}$ and the standard deviation of $\mathrm{ET}_{\mathrm{G}}$ at all the observation wells are showed in Figure 7. Temporal variations of $\mathrm{ET}_{\mathrm{G}}$ are obvious in the growing season. The average $\mathrm{ET}_{\mathrm{G}}$ is small $(1.5 \mathrm{~mm} / \mathrm{d})$ in the early April and gradually increases to peak values $(10.6 \mathrm{~mm} / \mathrm{d})$ at the end of July, then gradually decreases to $3.5 \mathrm{~mm} / \mathrm{d}$ at the end of October. The variation trend is consistent with daily average air temperature (Figure 7), indicating that seasonal $\mathrm{ET}_{\mathrm{G}}$ variation mainly depends on air temperature. However, the higher air temperature corresponds to the lower $\mathrm{ET}_{\mathrm{G}}$ in April. It may result from the less vitality of vegetation due to the less leaf area in the early growing season [42].

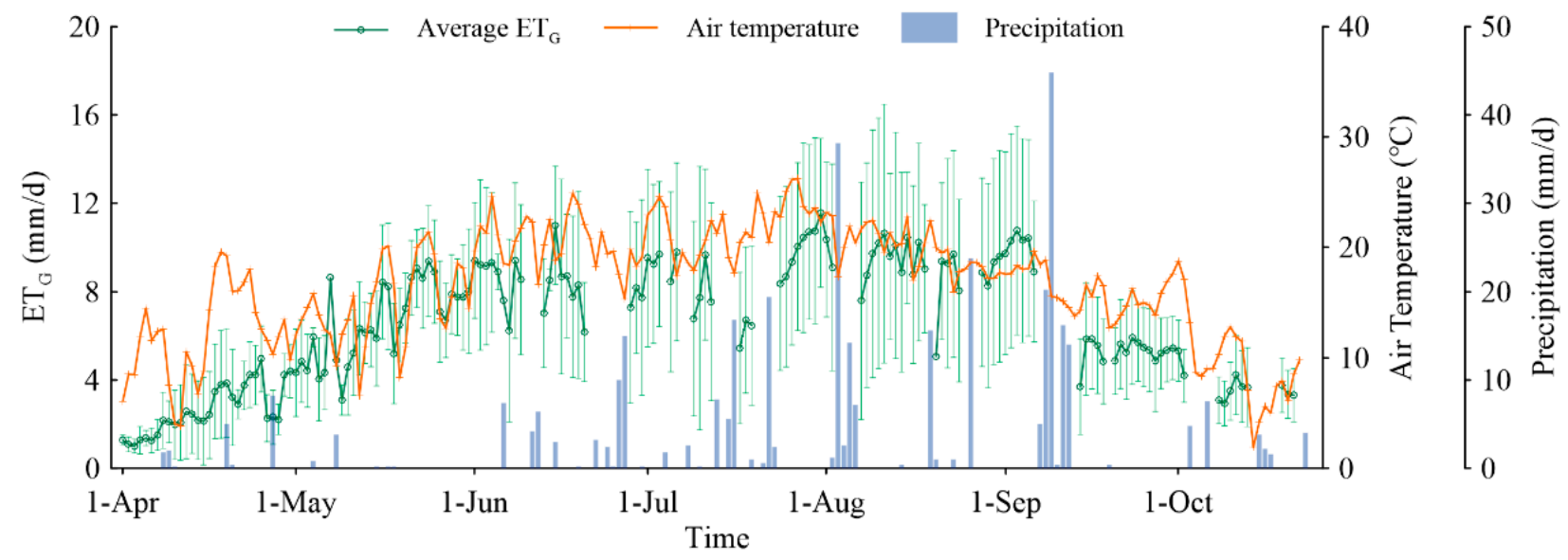

Figure 7. Average groundwater evapotranspiration $\left(\mathrm{ET}_{\mathrm{G}}\right)$ and the standard deviation of $\mathrm{ET}_{\mathrm{G}}$ at all the observation wells with air temperature and precipitation over the growing season.

\subsubsection{Spatial Variations of $\mathrm{ET}_{\mathrm{G}}$}

Spatial variation is significant indicated by the high standard deviation of the $\mathrm{ET}_{\mathrm{G}}$. The standard deviation shows a similar variation pattern to the average $\mathrm{ET}_{\mathrm{G}}$, which is small in the early and late growing season and large in the middle growing season. The large deviation $(4.2 \mathrm{~mm} / \mathrm{d}$ on average) in the middle of the growing season mainly depends on vegetations types and DWT of the observation wells. For example, the mean $\mathrm{ET}_{\mathrm{G}}$ in June was $10.9 \mathrm{~mm} / \mathrm{d}$ at K12 site with Populus alba, which was 1.7 times that of K14 $(6.4 \mathrm{~mm} / \mathrm{d})$ in the Carex stenophylla site with the same average DWT of $0.65 \mathrm{~m}$. On the other hand, the mean $\mathrm{ET}_{\mathrm{G}}$ was $2.9 \mathrm{~mm} / \mathrm{d}$ at K2 site with a mean DWT of $2.03 \mathrm{~m}$ and $4.1 \mathrm{~mm} / \mathrm{d}$ at K3 site with a mean DWT of $0.87 \mathrm{~m}$ in June for the Achnatherum splendens site. The spatial variations of $\mathrm{ET}_{\mathrm{G}}$ were also significant although the distance of two observations was small, for instance, the mean $\mathrm{ET}_{\mathrm{G}}$ of $\mathrm{K} 10$ was $5.8 \mathrm{~mm} / \mathrm{d}$ over the growing season in the Carex stenophylla site while there was no $\mathrm{ET}_{\mathrm{G}}$ at $\mathrm{K} 11$ in a sand dune even though it is only $20 \mathrm{~m}$ away from K10.

The higher standard deviation of $\mathrm{ET}_{\mathrm{G}}$ is also observed from the wells at the same vegetation site (Table 5). The mean standard deviation of average daily $\mathrm{ET}_{\mathrm{G}}$ at monthly scale are $1.76 \mathrm{~mm} / \mathrm{d}, 1.89 \mathrm{~mm} / \mathrm{d}$, and $3.43 \mathrm{~mm} / \mathrm{d}$ with the average daily $\mathrm{ET}_{\mathrm{G}}$ of $4.01 \mathrm{~mm} / \mathrm{d}$, $6.03 \mathrm{~mm} / \mathrm{d}$, and $8.96 \mathrm{~mm} / \mathrm{d}$ in the Achnatherum splendens site, Carex stenophylla site, and Salix psammophila site, respectively. It reflects that the average standard deviation increases with the average $\mathrm{ET}_{\mathrm{G}}$ in various vegetation sites. 
Table 5. The average groundwater evapotranspiration $\left(\mathrm{ET}_{\mathrm{G}}\right)$ and standard deviation at monthly scale for various vegetation sites.

\begin{tabular}{ccccccc}
\hline & \multicolumn{2}{c}{$\begin{array}{c}\text { Achnatherum splendens } \\
\text { Site }\end{array}$} & \multicolumn{2}{c}{ Carex stenophylla Site } & \multicolumn{2}{c}{ Salix psammophila Site } \\
\cline { 2 - 7 } & $\begin{array}{c}\text { Average } \\
\mathbf{E T}_{\mathbf{G}} \\
\mathbf{( m m} / \mathbf{d})\end{array}$ & $\begin{array}{c}\text { Standard } \\
\text { Deviation } \\
(\mathbf{m m} / \mathbf{d})\end{array}$ & $\begin{array}{c}\text { Average } \\
\mathbf{E T}_{\mathbf{G}} \\
(\mathbf{m m} / \mathbf{d})\end{array}$ & $\begin{array}{c}\text { Standard } \\
\text { Deviation } \\
(\mathbf{m m} / \mathbf{d})\end{array}$ & $\begin{array}{c}\text { Average } \\
\mathbf{E T}_{\mathbf{G}} \\
(\mathbf{m m} / \mathbf{d})\end{array}$ & $\begin{array}{c}\text { Standard } \\
\text { Deviation } \\
(\mathbf{m m} / \mathbf{d})\end{array}$ \\
\hline Apr-2019 & 3.11 & 2.40 & 2.05 & 0.86 & 6.58 & 0 \\
May-2019 & 4.07 & 1.82 & 6.71 & 1.48 & 8.76 & 1.76 \\
Jun-2019 & 3.69 & 2.20 & 7.75 & 2.18 & 10.51 & 5.60 \\
Jul-2019 & 4.31 & 1.32 & 7.96 & 2.38 & 10.70 & 3.80 \\
Aug-2019 & 4.54 & 1.45 & 7.93 & 2.58 & 12.60 & 5.45 \\
Sep-2019 & 4.18 & 1.66 & 6.07 & 2.21 & 9.25 & 2.31 \\
Oct-2019 & 3.19 & 1.49 & 3.71 & 1.53 & 4.29 & 1.67 \\
\hline
\end{tabular}

The large spatial difference of $\mathrm{ET}_{\mathrm{G}}$ at different wells reflects that $\mathrm{ET}_{\mathrm{G}}$ estimated by one observation well can only represent point-scale $\mathrm{ET}_{\mathrm{G}}$. However, Butler et al. [42] used a point-scale $\mathrm{ET}_{\mathrm{G}}$ to quantify the $\mathrm{ET}_{\mathrm{G}}$ of an area of $150 \mathrm{~m}^{2}$. According to our analysis, it may cause a large error to study regional $\mathrm{ET}_{\mathrm{G}}$ by a point value and the mean $\mathrm{ET}_{\mathrm{G}}$ of multiple wells in an area will be more representative, even though in the same vegetation site. Therefore, more observation wells are needed in an area to obtain a region-scale $\mathrm{ET}_{\mathrm{G}}$.

\subsubsection{Average $\mathrm{ET}_{\mathrm{G}}$ in Different Vegetation Sites}

For various vegetations, the average $\mathrm{ET}_{\mathrm{G}}$ over the whole growing season (April to October 2019) are $4.01 \mathrm{~mm} / \mathrm{d}, 6.03 \mathrm{~mm} / \mathrm{d}, 8.96 \mathrm{~mm} / \mathrm{d}$, and $12.26 \mathrm{~mm} / \mathrm{d}$ at the Achnatherum splendens site, Carex stenophylla site, Salix psammophila site, and Populus alba site with the average DWT of $1.19 \mathrm{~m}, 0.49 \mathrm{~m}, 1.30 \mathrm{~m}$, and $0.74 \mathrm{~m}$, respectively. It is obvious that the $\mathrm{ET}_{\mathrm{G}}$ in the tree sites is about twice as much as that of the grass sites. The same relationship has been found in previous studies [21,22]. For example, Satchithanantham et al. [22] found that the average $\mathrm{ET}_{\mathrm{G}}$ at trees sites and grass sites were $4.1 \mathrm{~mm} / \mathrm{d}$ and $2.1 \mathrm{~mm} / \mathrm{d}$, respectively, in the Assiniboine River drainage basin in southwestern Manitoba, Canada. Although the average $\mathrm{ET}_{\mathrm{G}}$ of trees and grass also shows two to one ratio, both of them are much less than that of our study. There are several possible reasons. Firstly, the average DWT in the Assiniboine River drainage basin (1.4 $\mathrm{m}$ for trees sites and $1.0 \mathrm{~m}$ for grass sites) was larger than that in our study site ( $1.1 \mathrm{~m}$ and $0.5 \mathrm{~m}$ for trees and grass sites, respectively). While groundwater absorbed by vegetation decreases with DWT [43]. Secondly, the annual precipitation in the Assiniboine River drainage basin was $474 \mathrm{~mm}$, being $44 \%$ larger than that of our study site $(330 \mathrm{~mm})$ due to the climate difference. Vegetation will use more soil water from rainfall infiltration than groundwater because the soil water is rich in nutrients and oxygen $[47,48]$. Finally, the $\mathrm{ET}_{\mathrm{G}}$ estimated method in our study considers the daily hydrostatic equilibrium recovery in capillary zones that is considered to be a part of $\mathrm{ET}_{\mathrm{G}}$.

\subsubsection{Sensitivity of $\mathrm{ET}_{\mathrm{G}}$ to Influencing Factors}

$\mathrm{ET}_{0}$ reflects the combined effect of individual meteorological variables because it is determined by solar radiation, air temperature, relative humidity, and wind speed (Equation (1)). As shown in Figure 8, $\mathrm{ET}_{\mathrm{G}}$ has a linear positive correlation with $\mathrm{ET}_{0}$ in each observation well. The slope of the linear expression of them are considered to be the parameter that reflects the relationship between $\mathrm{ET}_{\mathrm{G}}$ and $\mathrm{ET}_{0}$, and they are different among the wells. The slope in $\mathrm{K} 6, \mathrm{~K} 7$, and $\mathrm{K} 12$ are bigger than one (ranging from 1.03 to 1.78), indicating that the daily $\mathrm{ET}_{\mathrm{G}}$ in these wells are generally larger than daily $\mathrm{ET}_{0}$. The possible explanation is that the vegetation in $\mathrm{K} 6, \mathrm{~K} 7$, and $\mathrm{K} 12$ are trees that have larger $\mathrm{ET}_{\mathrm{G}}$ than grass. While $\mathrm{K} 4$ is close to the lake with dense grass, resulting in the larger $\mathrm{ET}_{\mathrm{G}}$. The slope in the other wells ranges from 0.46 to 0.91 . It reflects that the proportion of $\mathrm{ET}_{\mathrm{G}}$ and $\mathrm{ET}_{0}$ shows obvious spatial difference. However, the coefficient of determination $\left(\mathrm{R}^{2}\right)$ of 
the linear expressions is not suitable for all wells, ranging from 0.06 to 0.67 , resulting from other factors influencing $\mathrm{ET}_{\mathrm{G}}$. For example, $\mathrm{R}^{2}$ are 0.06 and 0.08 in $\mathrm{K} 2$ and $\mathrm{K} 7$, respectively, where DWT is larger.
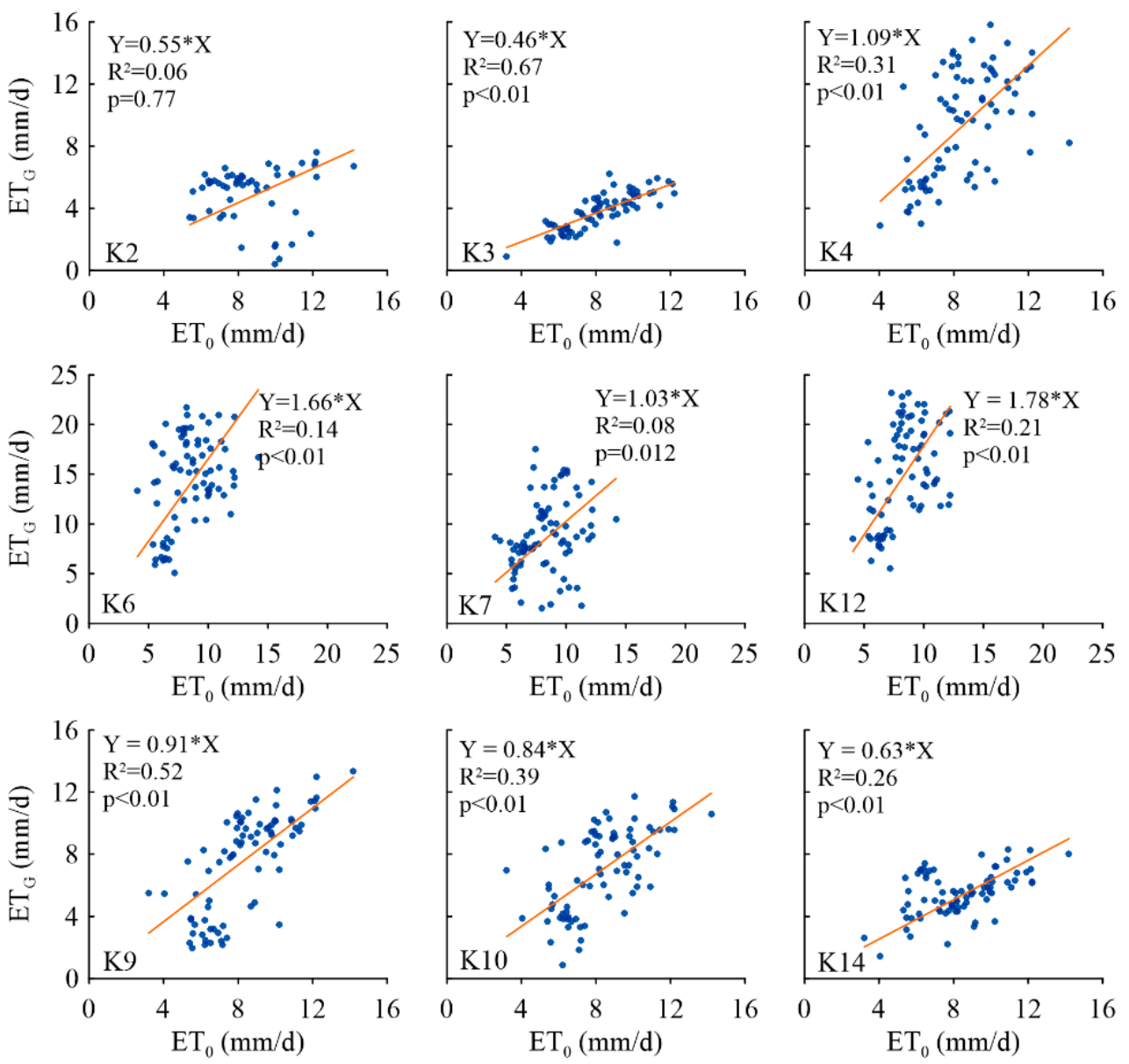

Figure 8. The relationship between $\mathrm{ET}_{0}$ and $\mathrm{ET}_{\mathrm{G}}$ for different observation wells.

In order to obtain the relationship between $\mathrm{ET}_{\mathrm{G}}$ and $\mathrm{DWT}$, a ratio of $\mathrm{ET}_{\mathrm{G}}$ to $\mathrm{ET}_{0}$ $\left(\mathrm{ET}_{\mathrm{G}} / \mathrm{ET}_{0}\right)$ are used to exclude the influence of climatic conditions. For various vegetation types, the exponential decay function between $\mathrm{ET}_{\mathrm{G}} / \mathrm{ET}_{0}$ and $\mathrm{DWT}$ are obtained as shown in Figure 9, but the parameters of these functions are different. The maximum $\mathrm{ET}_{\mathrm{G}} / \mathrm{ET}_{0}$ is 1.1 for the grass sites (the Carex stenophylla site and the Achnatherum splendens site), while the maximum $\mathrm{ET}_{\mathrm{G}} / \mathrm{ET}_{0}$ is 3.6 for the tree sites (the Populus alba site and the Salix psammophila site), resulted from the larger $\mathrm{ET}_{\mathrm{G}}$ in the tree sites. The coefficient of the independent variable $(\mathrm{CIV})$ in the exponential function can reflect the decay rate of the $\mathrm{ET}_{\mathrm{G}} / \mathrm{ET}_{0}$ with DWT. For grass, $\mathrm{ET}_{\mathrm{G}} / \mathrm{ET}_{0}$ decreases more rapidly with DWT in the Carex stenophylla site $(\mathrm{CIV}=-2.35)$ than in the Achnatherum splendens site $(\mathrm{CIV}=-1.55)$, indicating that $\mathrm{ET}_{\mathrm{G}}$ is more sensitive to DWT in the Carex stenophylla site. While $\mathrm{ET}_{\mathrm{G}} / \mathrm{ET}_{0}$ decreases more rapidly with DWT in the Populus alba site (CIV $=-2.66)$ than in the Salix psammophila site $(\mathrm{CIV}=-0.98)$ for the tree sites, suggesting that $\mathrm{ET}_{\mathrm{G}}$ in the Populus alba site is more sensitive to DWT.

The groundwater extinction depth is assumed to be reached when $\mathrm{ET}_{\mathrm{G}} / \mathrm{ET}_{0}$ decreases to $0.5 \%$ [49]. According to the relationship of $\mathrm{ET}_{\mathrm{G}} / \mathrm{ET}_{0}$ and DWT in our study site, the groundwater extinction depth are $4.1 \mathrm{~m}, 2.4 \mathrm{~m}, 7.1 \mathrm{~m}$, and $2.9 \mathrm{~m}$ in the Achnatherum splendens site, Carex stenophylla site, Salix psammophila site and Populus alba site, respectively. It reflects that roots of Achnatherum splendens and Salix psammophila are deeper and better able to adapt to lower water levels. 

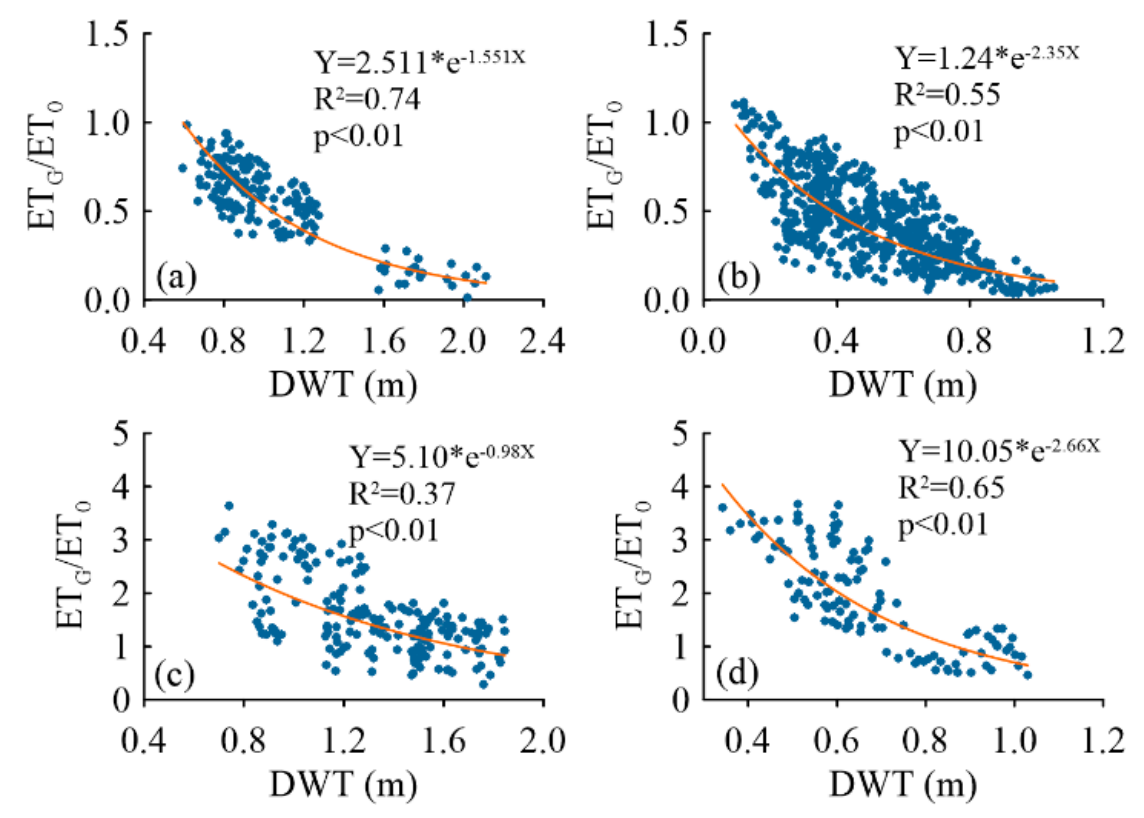

Figure 9. The relationship between the ratio of $\mathrm{ET}_{\mathrm{G}}$ to $\mathrm{ET}_{0}\left(\mathrm{ET}_{\mathrm{G}} / \mathrm{ET}_{0}\right)$ and $\mathrm{DWT}$ for (a) the Achnatherum splendens site, (b) the Carex stenophylla site, (c) the Salix psammophila site, and (d) the Populus alba site.

\section{Conclusions}

In this study, $\mathrm{ET}_{\mathrm{G}}$ of four vegetation types was estimated based on the diurnal water table and soil moisture fluctuations in the northeastern $\mathrm{Mu}$ Us sandy region. According to the variation of water table fluctuations at multiple wells, the influence of tidal and barometric pressure could be excluded. $\mathrm{ET}_{\mathrm{G}}$ in all the observation wells shows a significant temporal and spatial variation in each vegetation site, indicating that the representativeness of $\mathrm{ET}_{\mathrm{G}}$ from one observation well is poor and the mean $\mathrm{ET}_{\mathrm{G}}$ of multiple wells in an area will be more representative. The average $\mathrm{ET}_{\mathrm{G}}$ of multiple observation wells are $4.01 \mathrm{~mm} / \mathrm{d}$, $6.03 \mathrm{~mm} / \mathrm{d}, 8.96 \mathrm{~mm} / \mathrm{d}$ and $12.26 \mathrm{~mm} / \mathrm{d}$ at the Achnatherum splendens site, Carex stenophylla site, Salix psammophila site, and Populus alba site with the average DWT of $1.19 \mathrm{~m}, 0.49 \mathrm{~m}$, $1.30 \mathrm{~m}$, and $0.74 \mathrm{~m}$, respectively, in the whole growing season.

The main influencing factors of $\mathrm{ET}_{\mathrm{G}}$ are $\mathrm{ET}_{0}$ and DWT. The $\mathrm{ET}_{\mathrm{G}}$ is more sensitive to DWT in the Carex stenophylla site than that in the Achnatherum splendens site for grass sites, and for tree sites, $\mathrm{ET}_{\mathrm{G}}$ in the Populus alba site is more sensitive to DWT than that in the Salix psammophila site, according to the relationship between $\mathrm{ET}_{\mathrm{G}} / \mathrm{ET}_{0}$ and DWT. In addition, the groundwater extinction depths are also predicted to be $4.1 \mathrm{~m}, 2.4 \mathrm{~m}, 7.1 \mathrm{~m}$, and $2.9 \mathrm{~m}$ in the Achnatherum splendens site, Carex stenophylla site, Salix psammophila site, and Populus alba site, respectively. This typical geomorphic unit in the study area is thought to be able to represent the evapotranspiration characteristics of the groundwater-dependent vegetation covered area in the Mu Us Sandy region, northern China.

Author Contributions: Conceptualization, W.J. and L.Y.; methodology, W.J.; software, W.J.; validation, M.Z., F.H. and L.Y.; formal analysis, W.J.; investigation, W.J.; resources, L.Y.; data curation, W.J.; writing—original draft preparation, W.J.; writing—review and editing, L.Y.; visualization, K.Y.; supervision, L.W.; project administration, K.Y.; funding acquisition, L.Y. All authors have read and agreed to the published version of the manuscript.

Funding: This research was funded by China National Natural Science Foundation (41472228 and 41877199), Innovation Capability Support Program of Shaanxi (Program No. 2019TD-040), China Geological Survey (DD20160293), and Key Laboratory of Groundwater and Ecology in Arid Regions of China Geological Survey.

Institutional Review Board Statement: Not applicable. 
Informed Consent Statement: Not applicable.

Data Availability Statement: The data presented in this study are available on request from the corresponding author. The data are not publicly available due to privacy.

Acknowledgments: We sincerely acknowledge the anonymous reviewers and the Editor for their useful comments.

Conflicts of Interest: The authors declare no conflict of interest.

\section{References}

1. Bullock, J.M.; Aronson, J.; Newton, A.C.; Pywell, R.F.; Rey-Benayas, J.M. Restoration of ecosystem services and biodiversity: Conflicts and opportunities. Trends Ecol. Evol. 2011, 26, 541-549. [CrossRef]

2. Mvungi, A.; Mashauri, D.; Madulu, N. Management of water for irrigation agriculture in semi-arid areas: Problems and prospects. Phys. Chem. Earth Parts A/B/C 2005, 30, 809-817. [CrossRef]

3. Alvarez, M.D.P.; Trovatto, M.M.; Hernández, M.A.; Gonzalez, N. Groundwater flow model, recharge estimation and sustainability in an arid region of Patagonia, Argentina. Environ. Earth Sci. 2012, 66, 2097-2108. [CrossRef]

4. Wang, L.; Good, S.P.; Caylor, K. Global synthesis of vegetation control on evapotranspiration partitioning. Geophys. Res. Lett. 2014, 41, 6753-6757. [CrossRef]

5. Li, X.; Gentine, P.; Lin, C.; Zhou, S.; Sun, Z.; Zheng, Y.; Liu, J.; Zheng, C. A simple and objective method to partition evapotranspiration into transpiration and evaporation at eddy-covariance sites. Agric. For. Meteorol. 2019, 265, 171-182. [CrossRef]

6. Xiu, L.; Yan, C.; Li, X.; Qian, D.; Feng, K. Monitoring the response of vegetation dynamics to ecological engineering in the Mu Us Sandy Land of China from 1982 to 2014. Environ. Monit. Assess. 2018, 190, 543. [CrossRef]

7. Lu, C.; Zhao, T.; Shi, X.; Cao, S. Ecological restoration by afforestation may increase groundwater depth and create potentially large ecological and water opportunity costs in arid and semiarid China. J. Clean. Prod. 2018, 176, 1213-1222. [CrossRef]

8. Gribovszki, Z.; Kalicz, P.; Balog, K.; Szabó, A.; Tóth, T.; Csáfordi, P.; Metwaly, M.; Szalai, S. Groundwater uptake of different surface cover and its consequences in great Hungarian plain. Ecol. Process. 2017, 6, 39. [CrossRef]

9. Yin, L.; Hu, G.; Huang, J.; Wen, D.; Dong, J.; Wang, X.; Li, H. Groundwater-recharge estimation in the Ordos Plateau, China: Comparison of methods. Hydrogeol. J. 2011, 19, 1563-1575. [CrossRef]

10. Doody, T.M.; Benyon, R.G.; Theiveyanathan, S.; Koul, V.; Stewart, L. Development of pan coefficients for estimating evapotranspiration from riparian woody vegetation. Hydrol. Process. 2013, 28, 2129-2149. [CrossRef]

11. Liou, Y.-A.; Kar, S.K. Evapotranspiration Estimation with Remote Sensing and Various Surface Energy Balance Algorithms-A Review. Energies 2014, 7, 2821-2849. [CrossRef]

12. Anapalli, S.S.; Fisher, D.K.; Reddy, K.N.; Wagle, P.; Gowda, P.H.; Sui, R. Quantifying soybean evapotranspiration using an eddy covariance approach. Agric. Water Manag. 2018, 209, 228-239. [CrossRef]

13. White, W. A Method of Estimating Ground-Water Supplies Based on Discharge by Plants and Evaporation from Soil: Results of Investigations in Escalante Valley; US Geological Survey: Salt Lake, UT, USA, 1932.

14. Cheng, D.-H.; Li, Y.; Chen, X.; Wang, W.-K.; Hou, G.-C.; Wang, C.-L. Estimation of groundwater evaportranspiration using diurnal water table fluctuations in the Mu Us Desert, northern China. J. Hydrol. 2013, 490, 106-113. [CrossRef]

15. Yin, L.; Zhou, Y.; Ge, S.; Wen, D.; Zhang, E.; Dong, J. Comparison and modification of methods for estimating evapotranspiration using diurnal groundwater level fluctuations in arid and semiarid regions. J. Hydrol. 2013, 496, 9-16. [CrossRef]

16. Gribovszki, Z.; Kalicz, P.; Szilágyi, J.; Kucsara, M. Riparian zone evapotranspiration estimation from diurnal groundwater level fluctuations. J. Hydrol. 2008, 349, 6-17. [CrossRef]

17. Wang, T.-Y.; Wang, P.; Yu, J.-J.; Pozdniakov, S.P.; Du, C.-Y.; Zhang, Y.-C. Revisiting the White method for estimating groundwater evapotranspiration: A consideration of sunset and sunrise timings. Environ. Earth Sci. 2019, 78, 78. [CrossRef]

18. Ii, S.P.L. A method for estimating subdaily evapotranspiration of shallow groundwater using diurnal water table fluctuations. Ecohydrology 2008, 1, 59-66. [CrossRef]

19. Li, N.; Yan, C.; Xie, J. Remote sensing monitoring recent rapid increase of coal mining activity of an important energy base in northern China, a case study of Mu Us Sandy Land. Resour. Conserv. Recycl. 2015, 94, 129-135. [CrossRef]

20. Liang, P.; Yang, X. Landscape spatial patterns in the Maowusu (Mu Us) Sandy Land, northern China and their impact factors. Catena 2016, 145, 321-333. [CrossRef]

21. Cheng, D.-H.; Duan, J.; Qian, K.; Qi, L.; Yang, H.; Chen, X. Groundwater evapotranspiration under psammophilous vegetation covers in the Mu Us Sandy Land, northern China. J. Arid Land 2016, 9, 98-108. [CrossRef]

22. Satchithanantham, S.; Wilson, H.; Glenn, A.J. Contrasting patterns of groundwater evapotranspiration in grass and tree dominated riparian zones of a temperate agricultural catchment. J. Hydrol. 2017, 549, 654-666. [CrossRef]

23. Allen, R.G.; Pereira, L.S.; Raes, D.; Smith, M. Crop. Evapotranspiration-Guidelines for Computing Crop. Water Requirements; FAO: Rome, Italy, 1998.

24. Schelle, H.; Durner, W.; Iden, S.C.; Fank, J. Simultaneous Estimation of Soil Hydraulic and Root Distribution Parameters from Lysimeter Data by Inverse Modeling. Procedia Environ. Sci. 2013, 19, 564-573. [CrossRef] 
25. Nascimento, Í.V.; de Assis Júnior, R.N.; de Araújo, J.C.; de Alencar, T.L.; Freire, A.G.; Lobato, M.G.R.; da Silva, C.P.; Mota, J.C.A.; Nascimento, C.D.V. Estimation of van Genuchten Equation Parameters in Laboratory and through Inverse Modeling with Hydrus-1D. J. Agric. Sci. 2018, 10, 102. [CrossRef]

26. Mavimbela, S.S.W.; Van Rensburg, L.D. Estimating Soil Hydraulic Parameters Characterizing Rainwater Infiltration and Runoff Properties of Dryland Floodplains. Comput. Water Energy Environ. Eng. 2019, 8, 11-40. [CrossRef]

27. Šimůnek, J.; Šejna, M.; Saito, H.; Sakai, M.; Genuchten, M.T.V. The HYDRUS-1D Software Package for Simulating the One-Dimensional Movement of Water, Heat, and Multiple Solutes in Variably-Saturated Media; Version 4.17, HYDRUS Software Series 3; Department of Environmental Sciences, University of California Riverside: Riverside, CA, USA, 2013.

28. Li, Y.; Šimůnek, J.; Jing, L.; Zhang, Z.; Ni, L. Evaluation of water movement and water losses in a direct-seeded-rice field experiment using Hydrus-1D. Agric. Water Manag. 2014, 142, 38-46. [CrossRef]

29. Ritchie, J.T. Model for predicting evaporation from a row crop with incomplete cover. Water Resour. Res. 1972, 8, 1204-1213. [CrossRef]

30. Belmans, C.; Wesseling, J.; Feddes, R. Simulation model of the water balance of a cropped soil: SWATRE. J. Hydrol. 1983, 63, 271-286. [CrossRef]

31. Zeng, X. Global Vegetation Root Distribution for Land Modeling. J. Hydrometeorol. 2001, 2, 525-530. [CrossRef]

32. van Genuchten, M.T. A Numerical Model for Water and Solute Movement in and below the Root Zone; Unpublished Report; U.S. Salinity Laboratory, USDA, ARS: Riverside, CA, USA, 1987.

33. Willmott, C.J.; Ackleson, S.G.; Davis, R.E.; Feddema, J.J.; Klink, K.M.; LeGates, D.R.; O’Donnell, J.; Rowe, C.M. Statistics for the evaluation and comparison of models. J. Geophys. Res. Space Phys. 1985, 90, 8995-9005. [CrossRef]

34. Nash, J.E.; Sutcliffe, J.V. River flow forecasting through conceptual models part I-A discussion of principles. J. Hydrol. 1970, 10, 282-290. [CrossRef]

35. LeGates, D.R.; McCabe, G.J., Jr. Evaluating the use of "goodness-of-fit" Measures in hydrologic and hydroclimatic model validation. Water Resour. Res. 1999, 35, 233-241. [CrossRef]

36. Laczniak, R.J.; Smith, J.L.; Elliott, P.E.; DeMeo, G.A.; Chatigny, M.A.; Roemer, G.J. Ground-Water Discharge Determined from Estimates of Evapotranspiration, Death Valley Regional Flow System, Nevada and California; Report 2001-4195; U.S. Geological Survey: Reston, VA, USA, 2001.

37. Nachabe, M.H. Analytical expressions for transient specific yield and shallow water table drainage. Water Resour. Res. 2002, 38, 11-1-11-7. [CrossRef]

38. Ii, S.P.L.; Butler, J.J., Jr.; Gorelick, S.M. Estimation of groundwater consumption by phreatophytes using diurnal water table fluctuations: A saturated-unsaturated flow assessment. Water Resour. Res. 2005, 41, 1-14. [CrossRef]

39. Gribovszki, Z. Comparison of specific-yield estimates for calculating evapotranspiration from diurnal groundwater-level fluctuations. Hydrogeol. J. 2017, 26, 869-880. [CrossRef]

40. Freeze, R.A.; Cherry, J.A. Groundwater; Prentice-Hall, Inc.: Englewood Cliffs, NJ, USA, 1979.

41. Duke, H.R. Capillary Properties of Soils-Influence upon Specific Yield. Trans. ASAE 1972, 15, 0688-0691. [CrossRef]

42. Butler, J.J.; Kluitenberg, G.J.; Whittemore, D.O.; Ii, S.P.L.; Jin, W.; Billinger, M.A.; Zhan, X. A field investigation of phreatophyteinduced fluctuations in the water table. Water Resour. Res. 2007, 43, 299-309. [CrossRef]

43. Yue, W.; Wang, T.; Franz, T.E.; Chen, X. Spatiotemporal patterns of water table fluctuations and evapotranspiration induced by riparian vegetation in a semiarid area. Water Resour. Res. 2016, 52, 1948-1960. [CrossRef]

44. Hughes, C.; Kalma, J.D.; Binning, P.J.; Willgoose, G.R.; Vertzonis, M. Estimating evapotranspiration for a temperate salt marsh, Newcastle, Australia. Hydrol. Process. 2001, 15, 957-975. [CrossRef]

45. Senitz, S. Untersuchung und Anwendung kurzperiodischer Schwankungen des Grundwasserspiegels in Thüringen. Grundwasser 2001, 6, 163-173. [CrossRef]

46. Jiang, X.-W.; Sun, Z.-C.; Zhao, K.-Y.; Shi, F.-S.; Wan, L.; Wang, X.; Shi, Z. A method for simultaneous estimation of groundwater evapotranspiration and inflow rates in the discharge area using seasonal water table fluctuations. J. Hydrol. 2017, 548, 498-507. [CrossRef]

47. Scott, M.L.; Lines, G.C.; Auble, G.T. Channel incision and patterns of cottonwood stress and mortality along the Mojave River, California. J. Arid Environ. 2000, 44, 399-414. [CrossRef]

48. Martín, D.; Chambers, J. Restoration of riparian meadows degraded by livestock grazing: Above- and belowground responses. Plant Ecol. 2002, 163, 77-91. [CrossRef]

49. Shah, N.; Nachabe, M.; Ross, M. Extinction Depth and Evapotranspiration from Ground Water under Selected Land Covers. Groundwater 2007, 45, 329-338. [CrossRef] [PubMed] 